\title{
Innleggelser ved forverring av astma og kols
}

Engelsk oversettelse på www.tidsskriftet.no

\begin{abstract}
Sammendrag
Bakgrunn. Behandling av astma- og kolsforverringer bør ofte igangsettes raskt. Akuttinnleggelse i sykehus kan være nødvendig. Vi ønsket å kartlegge hva slags legekontakter pasientene hadde hatt og hva slags behandling de fikk før de ble innlagt med en slik forverring.
\end{abstract}

Materiale og metode. Et spørreskjema ble delt ut til pasienter over 18 år som var innlagt for astma- eller kolsforverring ved Helgelandssykehuset og ved Universitetssykehuset Nord-Norge i Tromsø fra januar 2010 til januar 2011. Pasientene svarte blant annet på spørsmål om varighet av forverringen, om legekontakter og om medisinsk behandling før innleggelsen.

Resultater. Svar fra 100 av 122 forespurte pasienter ble analysert. Median sykdomsvarighet ved første legekontakt var fire dager. 52 av pasientene hadde kontaktet fastlegen først, 40 kontaktet først legevakt og åtte tok direkte kontakt med sykehuset. Første kontakt med lege førte til innleggelse hos 56 pasienter, 21 (40\%) av dem som kontaktet fastlegen og 26 (70\%) av dem som kontaktet legevaktlege. 41 pasienter ble innlagt uten å være blitt klinisk unders $ø$ kt av innleggende lege samme dag, 32 etter telefonkonsultasjon med fastlege eller legevaktlege. Innleggelse uten klinisk undersøkelse forekom hyppigere hos dem som var over 70 år og hos dem som hadde vært innlagt tidligere.

Fortolkning. Pasienter med astmaeller kolsforverring blir ofte direkte innlagt etter telefonkonsultasjon med fastlege eller legevaktlege.

\section{Hasse Melbye}

hasse.melbye@uit.no

Allmennmedisinsk forskningsenhet

Institutt for samfunnsmedisin

Det helsevitenskapelige fakultet

Universitetet i Troms $\varnothing$

\section{Per Christian Moe}

Allmennmedisinsk forskningsenhet

Institutt for samfunnsmedisin

Det helsevitenskapelige fakultet

Universitetet i Tromsø

og

Lungemedisinsk avdeling

Hjerte-lungeklinikken

Universitetssykehuset Nord-Norge

\section{Frode Arstad}

Allmennmedisinsk forskningsenhet

Institutt for samfunnsmedisin

Det helsevitenskapelige fakultet

Universitetet i Tromsø

og

Medisinsk avdeling

Helgelandssykehuset

Sandnessjøen

Kronisk obstruktiv lungesykdom (kols) er karakterisert av en varig, ikke-reversibel reduksjon av lungefunksjonen og gir funksjonsnedsettelse og økt dødelighet (1). Diagnosen er en fellesbetegnelse for de obstruktive lungesykdommene emfysem og kronisk bronkitt. Pasienter med astma kan utvikle kols, noe som gjør gruppen kolspasienter enda mer sammensatt (2).

Akutte kolsforverringer er ledsaget av økt tungpustenhet og redusert livskvalitet og er ofte årsak til innleggelse i sykehus (3). En sykehistorie med hyppige forverringer øker risikoen for dette også i fremtiden (4) og gir dårligere prognose (5). En viktig målsetting i behandling og oppfølging av kols er derfor å redusere antall forverringer. Global Initiative for Chronic Obstruktive Disease (GOLD) publiserer veiledere for helsepersonell som behandler pasienter med kols (1). Vurdering av alvorlighetsgrad kan ifølge GOLD kreve utredning som vanligvis bare gjøres i sykehus, som røntgenundersøkelse og blodgassanalyse.

Målsettingen med denne undersøkelsen var å kartlegge hva slags legekontakter, undersøkelser og behandling pasienter innlagt med astma- og kolsforverringer har hatt like før innleggelsen. Spesielt ønsket vi å finne ut hvor stor andel av innleggelsene som var basert på telefonkonsultasjon med fastlege eller legevaktlege, og hvor ofte pasienten var blitt undersøkt klinisk av lege utenfor sykehus den dagen de blir innlagt.
For å kunne sette våre funn inn i en større sammenheng har vi innhentet tall fra Norsk pasientregister om sykehusinnleggelser som følge av astma- og kolsforverringer.

\section{Materiale og metode}

Pasienter over 18 år som ble skrevet ut fra Helgelandssykehuset eller Universitetssykehuset Nord-Norge mellom 10.1.2010 og 31.1. 2011 med hoveddiagnose astma- eller kolsforverring ble inkludert. Like før utskrivning eller etter hjemkomst ble de bedt om å fylle ut et spørreskjema om den aktuelle innleggelsen. De som ikke var mentalt i stand til å fylle ut skjemaet og de kritisk syke ble ikke spurt, og de som ble innlagt flere ganger i løpet av perioden skulle bare besvare skjemaet én gang. Pasientene ble spurt om varighet av forverringen, legekontakter og medisinsk behandling i forkant av sykehusinnleggelsen. Opplysninger om alder, kjønn, røykevaner og diagnose ble også etterspurt.

Før pasienten fikk skjemaet til utfylling hadde lege ved avdelingen registrert tre opplysninger fra journalen: siste lungefunksjonsmåling før innleggelse (forsert ekspiratorisk volum i ett sekund, $\mathrm{FEV}_{1}$ ), C-reaktivt protein (CRP) ved innleggelse og første registrerte $\mathrm{O}_{2}$-metning (målt ved blodgassundersøkelse eller pulsoksymetri, som regel på romluft) etter ankomst til sykehuset.

Pasientene ble tilbudt hjelp ved sengeposten til å fylle ut skjemaet, noe de fleste benyttet seg av. Noen fikk skjemaet sendt hjem per post etter utskrivning (en del av pasientene innlagt ved sykehusene i Mosjøen og Mo i Rana) og sendte det inn i ferdig frankert konvolutt.

Forskjeller mellom undergrupper av pasienter ble testet statistisk ved hjelp av khikvadrattest og Mann-Whitneys test. Programvaren SPSS 17.0 ble brukt i analysen, og et signifikansnivå på $5 \%$ ble valgt. Det ble ikke registrert personidentifiserbare opp-

\section{Hovedbudskap}

- Pasienter med astma- eller kolsforverring ble i mange tilfeller innlagt i sykehus uten klinisk undersøkelse hos innleggende lege samme dag

- Innleggelse via telefonkonsultasjon var vanligere hos pasienter som hadde vært innlagt med samme diagnose tidligere 
Tabell 1 Første legekontakt og behandling av 100 pasienter innlagt i sykehus pga. astma- eller kolsforverring

\begin{tabular}{|c|c|c|c|c|c|c|}
\hline & & \multicolumn{2}{|c|}{$\begin{array}{l}\text { Innlagt i forbindelse } \\
\text { med første kontakt }\end{array}$} & \multicolumn{3}{|c|}{ Ikke innlagt ved første kontakt } \\
\hline & & & & $\begin{array}{l}\text { Behandlet med antibiotika } \\
\text { og/eller prednisolon }\end{array}$ & $\begin{array}{l}\emptyset \text { kte bare daglig dose } \\
\text { av fast medisin }\end{array}$ & $\begin{array}{l}\text { Uendret } \\
\text { medisinbruk }\end{array}$ \\
\hline Første legekontakt & Antall & Antall & $(\%)$ & Antall & Antall & Antall \\
\hline \multicolumn{7}{|l|}{ Fastlege } \\
\hline Konsultasjon/sykebesøk & 27 & 10 & (37) & 9 & 2 & 6 \\
\hline Telefonkontakt & 25 & 11 & (44) & 6 & 3 & 5 \\
\hline \multicolumn{7}{|l|}{ Legevakt } \\
\hline Konsultasjon/sykebesøk & 21 & 16 & (76) & 3 & 1 & 1 \\
\hline Telefonkontakt & 19 & 12 & (63) & 3 & 1 & 3 \\
\hline Sykehuslege & 3 & 2 & (67) & 1 & 0 & 0 \\
\hline Dro rett på sykehus & 5 & 5 & $(100)$ & 0 & 0 & 0 \\
\hline Alle & 100 & 56 & $(56)$ & $22^{1}$ & 7 & 15 \\
\hline
\end{tabular}

lysninger, og $\mathrm{FEV}_{1}$, CRP og $\mathrm{SpO}_{2}$ ble registrert $\mathrm{i}$ intervaller. Undersøkelsen ble vurdert av regional komité for medisinsk og helsefaglig forskning til å være anonym (etter at CRP, $p \mathrm{O}_{2}$ og $\mathrm{FEV}_{1}$ ble angitt $\mathrm{i}$ intervaller) og til å kunne gjennomføres uten godkjenning.

Opplysninger om innleggelser i 2009 og 2010 ved norske sykehus med diagnosekode J44.0, J44.1, J44.9 eller J46 (ICD-10) ble innhentet fra Norsk pasientregister og sammenholdt med tall fra Statistisk årbok 2011 (6).

\section{Resultater}

Det var 122 pasienter som tilfredsstilte inklusjonskriteriene og som ble bedt om å fylle ut spørreskjemaet. Skjemaet ble besvart av 102 pasienter. Av disse hadde 100 svart på de sentrale spørsmålene om legekontakter før innleggelsen, og analysen er basert på disse 100. Det var 50 menn og 50 kvinner. 50 ble behandlet ved Universitetssykehuset Nord-Norge i Tromsø og 50 ved Helgelandssykehuset. Median alder var 73 år. 74 pasienter hadde tidligere vært innlagt for samme sykdom. Median varighet av forverringen ved første legekontakt var fire dager, ved innleggelse var median varighet sju dager. CRP-nivå (registrert hos 98 pasienter) var forhøyet $(>10 \mathrm{mg} / \mathrm{l})$ hos 73 (74\%), 32 (33\%) hadde et CRP-nivå på 80 $\mathrm{mg} / \mathrm{l}$ eller mer. $\mathrm{Sp} \mathrm{O}_{2}$ ble målt hos 97 pasienter og var $<92 \%$ hos $47(48 \%)$.

Den første legekontakten under forverringen var med fastlegen for 52 pasienter, 40 kontaktet legevakt først og åtte henvendte seg direkte til sykehuset (tab 1). Totalt ble 56 innlagt etter første kontakt, sjeldnere når fastlege ble kontaktet $(40 \%)$ enn når legevaktlege ble kontaktet $(70 \%)$. Av disse 56 ble 30 innlagt uten å være blitt klinisk undersøkt av innleggende lege (tab 1). Av de 44 som ble innlagt på et senere tidspunkt, ble 33 innlagt etter undersøkelse av fastlege eller legevaktlege, ni etter telefonkonsultasjon med innleggende lege, mens to dro rett på sykehuset. Totalt ble dermed 41 pasienter (41\%) lagt inn uten at de samme dag var blitt klinisk undersøkt av lege. Innleggelser uten klinisk undersøkelse var vanligere ved Helgelandssykehuset, $52 \%$, enn ved Universitetssykehuset Nord-Norge i Tromsø, $30 \%(\mathrm{p}=0,03)$, hos pasienter eldre enn 75 år sammenliknet med de yngre (51\% versus $26 \%$ og hos dem som hadde vært innlagt tidligere sammenliknet med dem som hadde sin første innleggelse med den aktuelle diagnosen $(50 \%$ versus $18 \%, \mathrm{p}=0,003)$.

Astma- eller kolsforverring var i 2010 hovedårsak til 9752 innleggelser hos personer over 18 år, fordelt på 6256 pasienter (7). Antall pasienter er trolig litt lavere enn anført, da de som har vært innlagt ved flere helseforetak i perioden, er blitt registrert flere ganger. 53,3\% av dem som hadde vært innlagt var kvinner, og $72 \%$ var over 65 år. Det var per 1.1. 2011 3,804 millioner mennesker over 18 år bosatt $i$ Norge (15). Den årlige frekvens av personer innlagt pga. astmaeller kolsforverring blir dermed i størrelsesorden $6256 / 3804000 \approx 1,6$ per 1000 innbyggere over 18 år.

Ved Helgelandssykehuset var det registrert 113 innleggelser i 2010, og ved Universitetssykehuset Nord-Norge 335 (7). Vi kan anta at halvparten av innleggelsene ved Universitetssykehuset Nord-Norge fant sted ved sykehusene i Narvik og Harstad. Når vi trekker fra disse, var det totalt ca. 300 innleggelser for astma- eller kolsforverring ved Helgelandsykehuset og Universitetssykehuset NordNorge i Tromsø i den aktuelle perioden. Omtrent en tredel av disse var imidlertid reinnleggelser. Det tilsier at det var ca. 200 pasienter som kunne vurderes for inklusjon i denne studien. 100 av disse ble inkludert.

\section{Diskusjon}

Studien viser at innleggelser av pasienter med alvorlig astma eller kols ofte skjer etter telefonkonsultasjon med lege eller ved at pasienten drar rett på sykehuset. I vårt materiale var bare 59 av innleggelsene $(59 \%)$ basert på en fersk klinisk undersøkelse. Pasienter som tidligere hadde vært innlagt med kols- eller astmaforverring, ble oftere innlagt via telefonkonsultasjon enn pasienter som ikke hadde vært innlagt med disse diagnosene tidligere (data ikke vist). Det kan tyde på at de som har vært innlagt med forverringer tidligere, ut fra egne erfaringer oftere er overbevist om at innleggelse er påkrevd. Den høye frekvensen av telefonkonsultasjoner kan også være en indikasjon på at klinisk undersøkelse og de testene primærlegen rår over, ikke blir tillagt stor vekt $\mathrm{i}$ beslutningen om innleggelse. Trolig mener både pasient og lege at undersøkelse på legekontor eller legevakt ikke vil bidra med noe vesentlig og konstruktivt og bare føre til ugunstig forsinkelse av sykehusinnleggelsen.

Innleggelse etter telefonkonsultasjon var vanligere på Helgeland enn i Tromsø. Dette kan skyldes varierende tilgjengelighet ved de kommunale legevaktene og forskjellig kultur når det gjelder krav om at primærlegen skal kvalitetssikre innleggelsene. Det kan også skyldes store variasjoner i avstand til legekontor og sykehus. Sannsynligheten for at pasientene ble innlagt etter telefonsamtale, økte med stigende alder. Legenes beslutninger var sikkert velbegrunnet når pasienten var velkjent eller åpenbart alvorlig syk. Men når dette skjer så hyppig som studien tyder på, kan man spørre seg om noen pasienter ville vært like godt tjent med et behandlingstilbud utenfor sykehus.

For øvrig kan telefonkontakt også føre til god rådgivning. En undersøkelse fra Storbritannia har vist at god tilgang til telefonrådgivning for kolspasienter kan bidra til en reduksjon i antall innleggelser (8).

Man kan spørre seg hvor representative funnene våre er. Det var ca. 200 innleggelser ved Helgelandssykehuset og Universitets- 
sykehuset Nord-Norge i Tromsø som kunne vurderes med henblikk på inklusjon i studien. Hvis vi trekker fra de som døde og de som var for syke eller for mentalt svekket til å besvare spørreskjemaet, var det antakelig ikke så mange flere enn de 122 som fikk utdelt skjemaet som kunne blitt inkludert. Ettersom svar fra 100 av disse ( $82 \%$ ) kunne analyseres, kan vi anta at resultatene er forholdsvis representative for sykehusene som deltok.

Alders- og kjønnssammensetningen i materialet samsvarer med de nasjonale tallene. Det kan imidlertid være forskjeller mellom landsdelene i Norge i hvordan primærlegenes portvaktfunksjon blir praktisert for denne type pasienter. Det kan også være feilkilder ved gjennomføringen av spørreskjemaundersøkelsen. Selv om pasientene ble spurt om hendelser i nærmeste fortid, kan noen likevel ha svart feil fordi de ikke husker detaljer i forløpet eller fordi spørsmål ble misoppfattet.

I denne studien ser vi virkeligheten fra et sykehusperspektiv. Et annet bilde hadde tegnet seg dersom vi hadde tatt utgangspunkt i alle pasienter med astma- eller kolsforverring og undersøkt hvor mange som kontakter lege og hvilken behandling som blir gitt. Da hadde vi sannsynligvis hatt et pasientmateriale der et mindretall ville ha blitt innlagt.

De som først kontaktet fastlegen, måtte dette materialet $\mathrm{i}$ gjennomsnitt vente lenger på innleggelse enn de som kontaktet legevakten (data ikke vist). Det kan avspeile at de som kontakter legevakten er sykere enn de som kontakter fastlegen. Det kan også hende at fastlegen er tryggere på å behandle pasienten utenfor sykehus enn legevaktlegen er, da han/hun lettere kan gi tett oppfølging.

Leger i primærhelsetjenesten har ikke entydige retningslinjer å holde seg til ved astma- og kolsforverringer. Spirometri kan belyse om pasientens respirasjon er blitt mer obstruktiv, CRP-måling kan gi informasjon om forverringens alvorlighetsgrad og sannsynligheten for bakteriell infeksjon $(9,10)$, og pulsoksymetri som viser redusert $\mathrm{SpO}_{2}$ kan også si noe om alvorlighetsgrad og gi holdepunkter for om oksygenbehandling bør gis. Nytten av disse undersøkelsene er imidlertid $\mathrm{i}$ liten grad evaluert ved astma- og kolsforverringer i allmennpraksis, og pulsoksymetri er den eneste av disse som blir anbefalt $\mathrm{i}$ internasjonale retningslinjer $(1,11,12)$.

Legen kan trenge slike redskaper når behandling av forverringer skal vurderes, i tillegg til god kjennskap til sykdommens alvorlighetsgrad, tidligere forverringer og komorbiditet hos pasienten. Klinisk undersøkelse er fortsatt viktig for å vurdere hvor medtatt pasienten er og om engstelse bidrar til pustebesværet. I mange tilfeller vil trolig fastlegen, med sin kjennskap til pasienten, være bedre rustet til å gjøre en god klinisk vurdering enn det legevaktlegen vil være.

I dag har primærlegen hovedsakelig to alternativer når det gjelder astma- og kolsforverringer: sykehusbehandling og behandling i hjemmet. Hvis det også hadde vært mulig å legge pasienten inn på en sykestue med tilgang til blodgassmåling, røntgenundersøkelse og ikke-invasiv respirasjonsstøtte, måtte primærlegen utvide sitt beslutningsgrunnlag og en grundig prehospital undersøkelse ville være enda mer relevant. I andre vestlige land er det med godt resultat prøvd ut hjemmebehandling, gjennomført av sykehuspersonell, av pasienter med kolsforverring som først var blitt undersøkt i mottakelsen med henblikk på innleggelse. Slik behandling er blitt ansett som egnet for omtrent en firedel av pasientene (13).

Nyere forskning på kols tyder på at det vil bli hensiktsmessig å dele inn kolssykdommen i undergrupper, som skal behandles forskjellig $(4,14)$. Det vil også få betydning for håndteringen av forverringer. Dette vil innebære behov for kunnskapsoppdatering, også for allmennleger, og utvikling av rutiner som inngir trygghet hos både fastleger og pasienter.

\section{Hasse Melbye (f. 1950)}

er dr.med. og professor i allmennmedisin. Han er leder for Allmennmedisinsk forskningsenhet, Universitetet i Troms $\varnothing$.

Forfatter har fylt ut ICMJE-skjemaet og oppgir ingen interessekonflikter.

\section{Per Christian Moe (f. 1976)}

er cand.med. og lege i spesialisering ved Lungemedisinsk avdeling. Hjerte-lungeklinikken, Universitetssykehuset Nord-Norge. Forfatter har fylt ut ICMJE-skjemaet og oppgir ingen interessekonflikter.

\section{Frode Arstad (f. 1971)}

er cand.med. og lege i spesialisering ved Medisinsk avdeling, Helgelandssykehuset, Sandnessjøen.

Forfatter har fylt ut ICMJE-skjemaet og oppgir ingen interessekonflikter.

\section{Litteratur}

1. GOLD. Global Strategy for Diagnosis, Management, and Prevention of COPD. wwW.goldcopd.org/guidelines-global-strategyfor-diagnosis-management html (30.1.2012).

2. Guerra S. Asthma and chronic obstructive pulmonary disease. Curr Opin Allergy Clin Immunol 2009; 9: 409-16.

3. Mannino DM, Buist AS. Global burden of COPD risk factors, prevalence, and future trends. Lancet 2007: 370: 765-73

4. Hurst JR, Vestbo J, Anzueto A et al. Susceptibility to exacerbation in chronic obstructive pulmonary disease. N Engl J Med 2010; 363: 1128-38.

5. Donaldson GC, Seemungal TA, Bhowmik A et al. Relationship between exacerbation frequency and lung function decline in chronic obstructive pulmonary disease. Thorax 2002; 57: 847-52.

6. Statistisk sentralbyrå. Statistisk årbok www.ssb.no/aarbok/tab/tab-105.html (30.1.2012).

7. Norsk pasientregister. Anonymt datauttrekk datert 5.7.2011. Oslo: Norsk pasientregister, Helsedirektoratet, 2011.

8. Hurst JR, Fitzgerald-Khan F, Quint JK et al. Use and utility of a 24-hour Telephone Support Service for 'high risk' patients with COPD. Prim Care Respir J 2010; 19: 260-5.

9. Dev D, Wallace E, Sankaran R et al. Value of Creactive protein measurements in exacerbations of chronic obstructive pulmonary disease. Respir Med 1998; 92: 664-7

10. Weis N, Almdal T. C-reactive protein - can it be used as a marker of infection in patients with exacerbation of chronic obstructive pulmonary disease? Eur J Intern Med 2006; 17: 88-91.

11. Institute for Clinical Systems Improvement. Diagnosis and management of COPD. www.icsi.org/ chronic_obstructive_pulmonary_disease/ chronic_obstructive_pulmonary_disease_2286.html (30.1.2012)

12. Dekhuijzen PN, Broeders ME, Tuut MK et al. Medicamenteuze behandeling van COPD. Ned Tijdschr Geneeskd 2008: 152: 1465-8

13. Kunnskapssenteret. Intermediære enheter og «hjemmesykehus» ved behandling av pasienter med akutt KOLS-forverring. www.kunnskapssenteret no/Nyheter/ $\%$ E2\%80\%9DHjemmesykehus\%E2\%80\%9D+gir+ f\%C3\%A6rre+reinnleggelser+for+personer+med+ akutt+forverring+av+KOLS.12325.cms (30.1.2012)

14. Miravitlles M. Cough and sputum production as risk factors for poor outcomes in patients with COPD. Respir Med 2011; 105: 1118-28.

Mottatt 3.11. 2011, første revisjon innsendt 11.1. 2012, godkjent 18.4. 2012. Medisinsk redaktør Merete Kile Holtermann. 